STUDIA UKRAINICA POSNANIENSIA, vol. II: 2014, pp. 63-69.

ISBN 978-83-936654-5-7. ISSN 2300-4754.

\title{
СУЧАСНА УКРАЇНСЬКА ТА БІЛОРУСЬКА ДИТЯЧА ЛІТЕРАТУРА ЯК ПРОБЛЕМА КОМПАРАТИВІСТИКИ
}

\author{
КАТЕРИНА ЗАЙЦЕВА
}

Київський національний університет імені Тараса Шевченка, Київ - Україна

\section{WSPÓŁCZESNA UKRAIŃSKA I BIAŁORUSKA LITERATURA \\ DLA DZIECI JAKO ZAGADNIENIE KOMPARATYSTYKI}

\author{
KATERYNA ZAJCEWA \\ Narodowy Uniwersytet im. Tarasa Szewczenki w Kijowie, Kijów - Ukraina
}

STRESZCZENIE. W artykule skupiono się na właściwościach rozwoju ukraińskiej oraz białoruskiej literatury dziecięcej w warunkach postkolonialnych. Autorka, dokonując przeglądu historii studiów nad literaturą dziecięca, analizuje ewolucję podejść do tego fenomenu na przełomie XX i XXI w.

\section{MODERN UKRAINIAN AND BELARUSIAN CHILDREN'S LITERATURE AS A PROBLEM OF COMPARATIVE STUDIES}

\author{
KATERYNA ZAITSEVA \\ National Taras Shevchenko University of Kyiv, Kyiv - Ukraine
}

ABSTRACT. The article deals with peculiarities of the development of Ukrainian and Belarusian children's literature in the postcolonial period. The research history of children's literature within the field of comparative studies is analyzed. The evolution of investigation approaches in relation to the children's literature phenomenon at the end of XX - beginning of XXI century is examined.

B заємини української літератури 3 іншими національними, насамперед слов'янськими, здавна перебувають у науковому компаративному дискурсі вітчизняних (I. Франко, Д. Чижевський, Г. Вервес, Д. Наливайко, Г. Грабович, В. Моренець) і зарубіжних дослідників (М. Неврлий, Б. Бакула, М. Ласло-Куцюк, В. Рагойша). Кінець ХХ ст. приніс Україні чергове національне відродження. Саме тоді, на думку О. Брайко, „настає конструктивний перелом у компаративних студіях”, адже „розширюється тло для усвідомлення своєрідності української літератури, й усвідомлення [...] «європейськості» й універсальної значущості вітчизняного письменства".

${ }^{1}$ О. Б р а й к о, Украӥнська компаративістика другої половини XX-початку XXI cm., [в:] Національні варіанти літературної компаративістики, (упоряд. Д. Наливайко), Київ 2009 , c. 409. 
На кінець XX - початок XXI ст. мультикультуральні студії, найрізноманітніші методології (еко-, феміністична, гей-лесбійська, постколоніальна критика, інтертекстуальний, етноімагологічний, наратологічний підходи тощо), частина 3 яких втратили актуальність у місцях свого виникнення, поширилися i почали активно застосовуватися на східнослов'янському терені. Завдяки цьому вивчення літературної системи того чи іншого народу стало всебічним, адже враховує різні контексти (історико-літературні, суспільно-політичні, культурні тощо). Науковий інтерес філологів до постколоніальних літератур, який виник ще в середині XX ст., з кожним роком лише набуває нового звучання/прочитання, зокрема в Україні. I тут компаративістика як метамова літературознавства (за Ф. Жостом, Е. Касперським) ${ }^{2}$ є найбільш гнучкою дисципліною, методою для дослідження різнонаціональних художніх текстів, зокрема і дитячої літератури.

Сучасна українська та білоруська дитяча література перебувають на стадії становлення. Вони обидві позначені маркером „постколоніальна”. Від 90-х років XX ст. і до сьогодні кожна з них розвивається у власному національному літературному процесі. До цього визнавалося існування досить штучного утворення „радянська дитяча література”, тому національний аспект і української, і білоруської літератури для дітей був доволі умовним. Нині обидві вони стверджуються не лише у власних національно-культурних координатах, а й світовому літературному просторі, зокрема міжслов'янському. Притому органічно і природно без накладання рамок закритого простору і без не менш штучного інтернаціоналізму. Поява значного масиву художніх текстів для дітей упродовж двох останніх десятиліть вимагає від критиків, літературознавців переосмислення феномену дитячої літератури. На нашу думку, саме компаративістика дає змогу показати особливості розвитку української та білоруської дитячої літератури в постколоніальний період, зокрема жанрово-тематичну та стильову парадигму, віддзеркалює стан досліджень у національному ${ }^{3}$ літературознавстві.

У попередній публікації няльних студій дитячої літератури як загальна теорія, контактні й трансферні студії, порівняльна поетика, жанрологія дитячої літератури, інтертекстуальні, імагологічні студії, порівняльна історіографія, історія досліджень дитячої

${ }^{2}$ Ф. Ж о с т, Порівняльне літературознавство як філософія літератури, (перекл. 3 франц. О. Романової), [в:] Сучасна літературна компаративістика: стратегії і методи, (ред. Д. Наливайко), Київ 2009, с. 59-91; Е. К а с п е р с ь к и й, Про теорію компаративістики, (перекл. з польськ. С. Яковенка), [в:] Література. Теорія. Методологія, (упоряд. Д. Уліцька), Київ 2008, с. 518-540.

${ }^{3}$ Мається на увазі українське та білоруське.

${ }^{4}$ К. 3 а й ц е в а, Сучасні компаративні дослідження дитячої літератури в Україні, [в:] „Літературознавчі студіï” (ред. Г. Семенюк), 2013, вип. 39 (ч. 1), с. 373-378. 
літератури ${ }^{5}$. Тут зупинимося детальніше на останньому напрямку, адже саме в його межах, звернувшись до соціокультурних контекстів і впливів, можна пояснити певні аспекти дослідження феномену дитячої літератури. Звісно, жоден літературознавець не може претендувати на повноту висвітлення тих чи інших літературних явищ й всеохопність суджень про них. Однак, зважаючи на магістральні, з нашої точки зору, теоретичні концепції вивчення дитячої літератури, що поширилися наприкінці XX - початку XXI ст., розглянемо особливості розвитку української та білоруської літератури для дітей.

За останнє десятиліття інтерес до дитячої літератури як об'єкта наукового пізнання значно пожвавився. Але говорити про достатню розробку ії проблем чи то про задовільний рівень осмислення, а відповідно й актуальний літературознавчий дискурс, присвячений винятково дитячим студіям, не доводиться. На нашу думку, вона й досі має маргінальний статус. Потверджує це той факт, що й методологічна база, й термінологічний інструментарій вивчення дитячої літератури перебуває на стадії формування. Свого часу слушно зауважила М. Славова, що дослідники дитячої літератури шукають „методологічних опор то в педагогіці та психоаналізі, то в теорії інформації та семіотиці, то в рецептивній естетиці та культурології”, 3 тих пір минуло більше десяти років, українські науковці здебільшого послуговуються термінологією і методологічними підходами зарубіжних дослідників у галузі дитячої літератури (ДЛ). Такі запозичення та адаптації теоретико-методологічного підгрунтя, звісно, сприяють розвитку наукових концепцій, однак існує загроза штучного перенесення термінологічної бази, принципів аналізу та ін., не відповідних місцевому національному контекстові або, що навіть гірше, - відживлення застарілої методології, яка абсолютно не відповідатиме проблемам сучасної гуманітаристики у глобалізованому світі та медійному середовищі.

Окрім того існує проблема, яка супроводжує ДЛ від моменту її з'яви, - це протиставлення, навіть певне протистояння педагогічного та естетичного. Чи актуально нині літературознавцю розглядати „естетичну проблематику крізь педагогічний ракурс", дітей? Не зважаючи на нестачу уваги до феномену дитячої літератури серед літературознавців, погляди їхні на неї різняться. Йдеться про досить розмите значеннєве поле, а це свідчить не так про дискусійність терміна, як про невиробленість поглядів, відсутність узгоджених критеріїв та оцінок серед дослідників. Наприклад, Л. Кіліченко акцентує на тому, що дитяча література - „це та література, яка відповідає рівневі дитячих знань, їхньому життєвому досвіду, психологічному розвиткові, має відповідну тематику й технічне оформлен-

\footnotetext{
${ }^{5}$ E. O' S u 11 i v a n, Comparing Children's Literature, [online:] http://www.gfl- journal.de/22002/osullivan.pdf

${ }^{6} \mathrm{M}$. С л а в о в а, Попелютка літератури. Теоретичні аспекти літератури для дітей, Київ 2002, с. 8.

${ }^{7}$ Там само, с. 9.
} 
ня. Це та література, яку пишуть для дітей дорослі. Все інше - дитяча творчість" ${ }^{\prime}$. Більшість дослідників також саме ці риси називає специфічними для дитячої літератури й завдяки їм виокремлює іï з усього масиву літератури, протиставляючи „дорослій”. С. Іванюк зауважує, що власне „педагогічною спрямованістю, дидактизмом цей різновид художньої творчості й відрізняється від інших" ". Власне педагогічний критерій часто можна пояснити запитами соціокультурних умов та геополітичною ситуацією. Наприклад, в радянські часи дитячій літературі приділяли увагу насамперед як дидактичному інструментові (звідси й тривале вивчення художніх творів із погляду педагогіки). До дитячої літератури ставилися „серйозно”, сама радянська влада опікувалася тим, про що/як писати для дітей, які жанри мають фігурувати в літературному процесі, тобто ідеологічна заангажованість і наснаженість літератури для дітей була такою як і для дорослих, окрім того підкріплювалася ще й морально-дидактичними акцентами. Як зазначає С. Іванюк, „найвартіснішими стали вважатися твори, що пропонували юному читачеві готові етичні взірці, варіанти поведінки в тих чи інших обставинах" ${ }^{\text {, }}$.

За сімдесят років існування Радянського Союзу та його інституту цензури дитяча література пережила багато пертурбацій. Це і заборона фольклорного жанру казки, і нівелювання естетичної складової, системне пропагування морально-етичних принципів комуністичного режиму, віддзеркалення тогочасних суспільно-політичних реалій тощо. Інтерес із боку дослідників літератури для дітей/юнацтва тоді був значний, та здебільшого, на нашу думку, він спричинявся запитами влади. Скажімо, письменники, які писали для дітей, менше страждали від переслідувань влади, ніж ті, що писали для дорослих, тому можемо припустити, що й дослідники ДЛ обирали для аналізу саме дитячі тексти, бо це було безпечніше. Цим ми не намагаємося ствердити, що їхні розвідки маловартісні й не заслуговують на увагу, однак без їх критичного переосмислення не обійтися.

Якщо педагогічну спрямованість дитячої літератури, про яку мовилося у радянський час чи у перші роки незалежності України/Білорусі, можемо собі пояснити, то той факт, що й нині деякі літературознавці не лише акцентують саме на ній, а й роблять її найбільш вагомою або й єдиною сферою досліджень дивує. Наприклад, 2009 року з'явилася розвідка В. Костюченка Літературними стежками. Нарис історї украӥнської літератури для дітей $X X$ століття, в якій автор, послуговуючись історико-хронологічним принципом, описує історію ДЛ за десятиліттями. Дослідник пропонує такий підхід:

Літературі для дітей [...] властиві всі ті ознаки, що й „дорослій” літературі. Та й твориться вона за тими ж законами художності. А чи існує взагалі специфіка літератури

\footnotetext{
${ }^{8}$ Л. К і л і ч е н к о, Українська дитяча література, Київ 1988, с. 16.

${ }^{9}$ С. І в а н ю к, Випробування дитинством, [в:] „Сучасність” 1992, № 3, с. 176.

${ }^{10}$ Там само, с. 179.
} 
для дітей? [...] головна відмінність (специфіка) - вікова: що сказати, як сказати і коли сказати ${ }^{11}$.

Не зважаючи на це, автор таки лишається на позиціях педагогіки, а у своїх прогнозах розвитку ДЛ у XXI столітті доволі скептичний, називаючи Л. Воронину, О. Гавроша, Г. Малик, 3. Мензатюк молодим незнайомим плем'ям „3 ознаками сучасних есемес-технологій”, котре „бере на себе відповідальність за ідейне, літературно-естетичне і моральне виховання українських дітей”,

На початку XXI століття в Україні змінюється характер студій дитячої літератури. Цьому насамперед сприяли розвідки М. Славової Попелюшка літератури (2002), О. Папуші Наратив дитячої літератури: специффіка художнього дискурсу (2003), У. Гнідець Специифіка комунікаиії у літературі для дітей та юнацтвва (2008), Б. Салюк Типологія традииійних образів дитини-бешкетника у художніх творах для дітей $i$ про дітей (2011) та ін. Одна 3 найцитованіших у межах українського літературознавства, присвяченого проблемам ДЛ, дослідниця У. Гнідець, робить спробу виокремити в науковому дискурсі поняття “література для підлітків (юнацтва)", яке, на ii думку, є особливим специфічним феноменом, котрий

формується за власними, відмінними від літератури для дітей і літератури для дорослих, законами. 3 одного боку, її наративний дискурс структурується простотою мовлення $з$ урахуванням попереднього дитячого досвіду прочитання, а 3 іншого, - його ідеологія ініціації переповнена „дорослістю” реалістичних тем ${ }^{13}$.

Таким чином дослідниця розрізняє дитячу літературу й ніби проміжну ланку між нею і дорослою, причому основну увагу присвячує саме цьому адаптаційному переходу - підлітковій літературі. Аналітичний погляд на поставлені питання дає підстави стверджувати, що вони абсолютно не нові, адже й радянська дитяча література мала подібні проблеми ${ }^{14}$.

Науковий дискурс, що стосується білоруської дитячої літератури, розвивається ще повільніше. Її дослідники менше вдаються до нових підходів у вивченні (інтерпретації) художніх текстів. Тут проблемнішим є канонотвореня ДЛ в іiі межах, визначення іiі місця у культурному просторі. Наприклад, В. Жибуль акцентує на тому, що спроби вписати дитячу літературу „в контекст загальнолітературного процесу часто мають однобічний характер”,

${ }^{11}$ В. К о с т ю ч е н к о, Літературними стежками. Нарис історії украӥнської літератури для дітей ХХ століття, Київ 2009, с. 5.

12 Там само, с. 324.

${ }^{13}$ У. Г н і д е ц ь, Література для юнацтва: простота і складність (на прикладі роману „Маргаритко, моя квітко” Крістіне Нестлінгер), [в:] „Література. Діти. Час” (ред. Б. Будний), 2012, вип. 2, с. 21.

${ }^{14}$ На цьому акцентувала ще 1954 року Н. Забіла у статті Украйнська новітня література для дітей, [в:] Украӥнська дитяча література, (упоряд. І. Луценко), ч. 2, Київ 1992, с. 13.

${ }^{15}$ В. Ж и б у л ь, Детская поэзия Серебряного века. Модернизм, Минск 2004, с. 4. 
адже зазвичай цього прагнуть самі дослідники ДЛ. У кінці XX ст. в літературі „панівним стає локальний патріотизм” і „спостерігається відхід від ідеї сліпої відданості державі" ${ }^{\prime 16}$, це, зокрема, обумовило домінування історичної тематики як в українській прозі для дітей, так і білоруській. Наприклад, у Білорусі з'являються твори С. Тарасова про видатних історичних осіб - Ф. Скорину, Л. Сапєгу, К. Острозького. Тут є певна типологічна схожість між українською i білоруською дитячими літературами. Адже в Україні в перші роки незалежності інтерес до історичної тематики також був значний. Видавництво „Веселка" друкує багато творів, присвячених минулому, зокрема виходить книга історичного українського оповідання в чотирьох томах - Дерево пам'яті (1990-1995).

Ця тенденція помітна й нині. Оскільки історія завжди була інструментом маніпуляції та впливу, то в сьогоднішніх українських культурних реаліях неабиякої ваги набуває сучасна історична проза для дітей (це переважно історії про козаків). Варто зазначити, що 2012 року вперше Шевченківську премію отримав дитячий автор В. Рутківський за трилогію Джури (Джури козака Швайки - 2007 р., Джури-характерники - 2009 р., Джури і підводний човен - 2010 р.). 3-поміж інших творів цього автора на відповідну тематику, можемо назвати Сині води (2011р.) та Сторожова застава (2012р.). Сьогодні в українській дитячій літературі історична тема представлена текстами таких авторів, як 3. Мензатюк (Таємниия козаиької шаблі- 2006 р.), О. Гавроша (Пригоди тричі славного розбійника Пинті - 2008 р.), М. Морозенко (Іван Сірко великий характерник - 2010 р., Іван Сірко славетний кошовий - 2013 р.) та ін.

Чи не найпопулярнішим лишається жанр літературної казки (С. Дерманський, В. Вздульська, 3. Мензатюк, Л. Воронина), хоча йому доводиться „конкурувати" з фентезі, яке нині успішно розвивається в ДЛ, зокрема українській (М. Рибалко, О. Росич, М. та С. Дяченки). Шкільний роман, шкільна повість теж лишаються популярними, однак тут з'являється проблема героя-сучасника. Успішно в цьому жанрі працюють Вс. Нестайко, В. Бердт, О. Лущевська, М. Павленко, І. Андрусяк та ін.

На початку XXI ст. активно видаються нариси, подорожні нотатки про історію Білорусі, наприклад, К. Тарасов Беларусь. Гістарычнае падарожжа для дзяцей (2000р.), Ул. Бутрамеева Вялікія і славутыля людзі зямлі Беларусі (2005р.), оповідання С. Тарасова зі збірки Фрэскі. В сучасній українській дитячій літературі цей жанр широко не заявлений. Хоча в українській радянській був представлений творчістю письменника-мандрівника Л. Тендюка Вогники в океані (1974 p.), Дивовижна риба мурена (1977 p.), На коралових атолах (1979 р.), трилогія Експедииія „Гондвана” (1984р.), Одіссея східних морів (1964 р.), Шукачі тайфунів (1965р.) та ін. Коли йдеться про характерні риси

${ }^{16}$ В. К а р а т к е в і ч, Я. К л і м у ц ь, І. К у л ь б я н к о в, Беларуская дзіиячая літаратура на сучасным эпате, [в:] Беларуская дзічячая літаратура, (рэд. А. Макарэвіча), Мінск 2008, c. 492. 
білоруської „дитячої” прози кін. XX - поч. XXI ст., дослідники акцентують на „послідовному засвоєнні традицій”, на морально-етичній проблематиці, яка присутня „у більшості творів різних жанрів" ${ }^{, 17}$, скажімо, в оповіданнях Л. Арабей Новае сяброўства (1989р.), Птушка Хірасімы (1989р.), Калібры (1989 р.) тощо.

Причиною обмеженої уваги до дитячої літератури у Білорусі, на нашу думку, $є$ те, що білоруськомовних текстів менше, аніж російськомовних. Вчені переважно вивчають російську дитячу літературу (В. Жибуль, Детская поэзия серебряного века. Модернизм - 2004 г.). Маємо констатувати, що білоруська дитяча література введена в науковий дискурс доволі фрагментарно, розглядається переважно з позицій педагогіки, а не літературознавства. Чи не найгрунтовнішим лишається дослідження Беларуская дзіиячая літаратура ${ }^{18}$ (однак, історія ДЛ тут подається крізь призму педагогічного підходу). Можемо констатувати, що суспільно-політичні зміни в Україні та Білорусі наприкінці XX - початку XXI ст. вплинули як на літературний процес загалом, так i на літературу для дітей зокрема. Це і жанрові зміни (фентезі, альтернативна історія, фан-фік, „дитячий” детектив, комікси тощо), і тематичні тощо.

Існування феномену дитячої літератури є досить складною проблемою літературознавства. У подальших порівняльних дослідженнях української дитячої літератури варто зупинитися на контактних й трансферних студіях ${ }^{19}$. Ідеться про культурний обмін між різнонаціональними дитячими літературами через переклади. Справді, значної ваги набуває вивчення феномену літератури для дітей із позицій компаративістики, оскільки уможливлює входження української дитячої літератури у світовий контекст. Окрім того дослідження дитячої літератури дає змогу з'ясувати особливості національних літератур, їхнє місце в літературному процесі, а також показати перспективи та можливості сучасного порівняльного літературознавства як системи методів і науки.

\footnotetext{
${ }^{17}$ Там само, с. 482.

${ }^{18}$ Беларуская дзіиячая літаратура, зазнач. джерело.

${ }^{19}$ Е. O' S u 11 i v a n, зазнач. джерело, [online:] http://www.gfl-journal.de/2-2002/ osullivan.pdf.
} 